Article

\title{
Surrealist Sources \\ of Eastern European Animation Film
}

DE DE GRUYTER

OPEN

ÜLO PIKKOV, Estonian Academy of Arts; email: ylo.pikkov@artun.ee 


\section{ABSTRACT}

This article investigates the relationship between surrealism and animation film, attempting to establish the characteristic features of surrealist animation film and to determine an approach for identifying them. Drawing on the interviews conducted during the research, I will also strive to chart the terrain of contemporary surrealist animation film and its authors, most of who work in Eastern Europe. My principal aim is to establish why surrealism enjoyed such relevance and vitality in post-World War II Eastern Europe. I will conclude that the popularity of surrealist animation film in Eastern Europe can be seen as a continuation of a tradition (Prague was an important centre of surrealism during the interwar period), as well as an act of protest against the socialist realist paradigm of the Soviet period.

\section{INTRODUCTION}

Surrealism in animation film has been an under-researched field. While several monographs have been written on authors whose work is related to surrealism (Jan Švankmajer, Brothers Quay, Priit Pärn, Raoul Servais and many others), no broader studies on the matter exist. Most likely it is the result of the relative marginality of animation film as compared to mainstream cinema and its main agent, the feature length narrative film, which is the focus of the majority of work on surrealism in cinema (with an exception of Jan Švankmajer's oeuvre, which has recently attracted remarkable interest among film scholars). In addition, the activities of surrealists and their circles are rather poorly documented, which sets additional limits to research.

My investigation adopts qualitative research methods, providing inductive reasoning and interpretation of the subject (surrealism in animation film) and drawing on semi-structured interviews. The content analysis of films concentrates on the meaning assigned to the work by its author, keep- ing also in sight the spatiotemporal context of production.

It must be established from the outset that there are many ways to understand and interpret the notion of "surrealist animation film". In everyday use, "surreal" often stands for something obscure and incomprehensible. In art history, however, it signifies a set of practices and theories of a certain 20th-century avant-garde movement. In studying surrealism in animation film I will subscribe to this art historical frame of reference. Raphaëlle Moine and Pierre Taminiaux observed in their 2006 study that attempts to establish surrealist film as a genre lead to simplification and institutionalization (Moine, Taminiaux 2006: 114). In order to avoid excessive simplification and institutionalization of surrealist animation film, I will focus on surrealism in animation film, rather than surrealist animation film as a genre. I understand animation film as an audiovisual work recorded frame by frame, which aesthetically or at least formally conforms to the classical concept of cinema. Animation essentially involves 
the presentation of still images in a manner that creates an illusion of motion in viewers' minds. (Pikkov 2010: 14) By Eastern Europe, I mean the geopolitical region that after World War II was under Soviet rule or influence.

\section{THE ADVENT OF SURREALISM}

Surrealism is one of the most often described and reproduced phenomena of 20th-century art. Who is not familiar with Dali's melting watches, Magritte's men with top hats or the shots of an eye sectioned with a knife in Buñuel's Un Chien Andalou? - these and many other "surreal" images have become the staple of modern popular culture. Barbara Creed (2007: 116) argues, "[t]he surrealist movement of the 1920s was short-lived, but it continued to exert a marked influence on artistic practice and popular culture." Surrealism appeared on the global cultural map after World War I on the initiative and under the leadership of the French writer André Breton (1896-1966). While Dadaism and futurism should be mentioned as forerunners of or at least influences on the movement, surrealists themselves had the habit of emphasizing its uniqueness and independence: "Surrealism began among poets whose aim was to create a revolution, both political and artistic, combining the visions of Freud, Marx, Sade and Lautréamont." (Brandon 1999:3)

The heyday of surrealism as an art movement was the interwar period, yet it has retained its importance to this date. Surrealism is not a style in the narrow sense, but rather an author's worldview and attitude, although even its creators were unable to define it exhaustively. Surrealists considered society and culture as oppressive of human freedom and true needs, attempting to liberate the concealed powers in people, particularly their spontaneous and subconscious faculties of expression. Doing this, they drew on the teachings of Sigmund Freud (1856-1939), the founding father of psychoanalysis. Surrealists aimed at blurring the boundaries between art and life, and replacing the old, oppressive society with one that would meet peo- ple's true needs. Surrealists regarded spontaneity and expression of subconscious urges as an instrument to liberate people from the reins of the reason-based society.

The first Surrealist Manifesto was published in November 1924, a moment now considered the "official" birth date of surrealism. In the Manifesto, Breton defines surrealism in following terms: "Pure psychic automatism by means of which one intends to express, either verbally, or in writing, or in any other manner, the actual functioning of thought. Dictated by thought, in the absence of any control exercised by reason, free of any aesthetic or moral concern." (Breton [1924] 2010)

Surrealism is based on a belief in a higher reality of certain neglected forms of association, the omnipotence of dreams, the idle play of thinking. The Manifesto is in fact more a call for a new understanding of art (life) than a definition of a new modernist art movement. The surrealists sought to transcend the boundaries of the traditional field of art and were interested in transforming the people and the society at large.

\section{SURREALISTS AND CINEMA}

According to Linda Williams (1981: 51), "[s]urrealist ... filmmakers were ... the first to take seriously the striking resemblance between the film's imaginary signifier and that of the unconscious." Surrealist filmmakers, as surrealists in general, do not divide the world into the inanimate and the alive, for them everything is animist, i.e. related to everything else and in possession of a soul. As Williams (ibid.) explains it, "[i]nstead of showing what a character thinks, the Surrealist tendency in film was to show how images themselves can "think"”. As a mirror of modern times and lifestyle, cinema quickly caught the attention of surrealists, becoming an object of discussion and a field of experimentation. "Many of the early Surrealists (Luis Buñuel, André Breton, Jean Goudal, Ado Kyrou, Jean Ferry and others) fell in love with the fledgling cinema and its power to ... follow the movements of the dream-world." (Creed 2007: 118) Salvador Dalí and Luis 
Buñuel collaborated on two films (Un Chien Andalou, 1929; L'Age d'Or, 1930), which have become landmarks of both surrealism and cinema; film as a medium also fascinated Man Ray, Robert Desnos, Marchel Duchamp and many others, yet in contrast to painting cinema was never properly theorized by surrealists, they "did not have, properly speaking, a cinematographic doctrine", as Georges Sadoul put it (ibid.). The first more comprehensive analysis of surrealist cinema, Le Surréalisme au cinema (1953, updated 1963), was written by the critic and surrealist filmmaker Ado Kyrou (19231985).

The tenets of contemporary animation film developed in parallel to the advent and evolution of surrealism, as the initial isolated experiments gradually accumulated into a separate film form and an industrial branch. Animation film became one of the corner stones of popular culture and had maintained this position to this date. The interwar period has also been designated as the "Golden era" of animation film (Wells 2002: 2). During these years the first major studios were established (Disney, Fleischer, Walter Lantz) and several still popular characters launched their screen careers. The aesthetic framework and spectatorial expectations were also shaped during this golden age of animation, largely based on Disney's popularly successful work. The period also saw the birth of Destino, perhaps the most legendary surrealist animation film, which, however, remained uncompleted until 2003. Salvador Dalí met Walt Disney in 1945 (King 2007: 87), in order to collaborate on a six-minute animation film (ibid., 88). Yet in 1946 Disney, unconvinced of its potential audience appeal, halted the production on its tracks, although in the hope of returning to it at a later date (ibid., 91). In 1999 the Disney corporation discovered that the copyright of Dalî's designs for Destino (about 135 drawings and 32 paintings), worth at that point approximately 10 million USD, did not belong to Disney after all, since the film was never completed (ibid., 92). Disney restarted Destino's production, assigning Dominique Monfrey as its new director, and the film premiered in 2003. This way Disney managed to re-claim the copyright of Dalî's original designs.

Created as a computer animation, Destino includes and builds upon Dalís images, 15 seconds of which were part of an initial screen test by Dali (ibid.). Yet even if Destino is based on the work of one of the most famous surrealists, the question remains whether it is an essentially surrealist film. For designating an animation film as surrealist is it enough to use Dalís images, or does it take something more?

\section{THE SURREALIST ESSENCE OF ANIMATION FILM}

Modernist art movements, including surrealism, are defined by a strive towards creating something completely new and unprecedented, an impulse of qualitative progress. Similarly, the first animation films quite noticeably attempted to surprise the audiences with something original and extraordinary. In addition to this gravitation towards novelty, animation film and surrealism share other common traits. Although 1924 is acknowledged as the birth date of surrealism, certain surrealist ideas circled in the art world even earlier, exerting certain influence on the development of animation film. For instance, describing the work of one of the earliest animation filmmakers, Winsor McCay (1869-1934), Judith O'Sullivan observes that his art nouveau comic strips, as well as his later films, reveal several surrealist features - anxiety, hostile atmosphere, objects coming together in irrational conjunctions, constantly threatening mechanical devices (Wells 2002: 31). From today's point of view, several pioneers of animation film, such as Ladislas Starevich, Émile Cohl, James Stuart Blackton and many others, can be considered proponents of surrealism. The abstract animation films of Viking Eggeling, Hans Richter, Walter Ruttmann and Oskar Fishinger from the interwar period also betray dadaist and surrealist impulses. 
Furthermore, "proto-surrealist" authors such as Giuseppe Arcimboldo, Hieronymus Bosch, Marquis de Sade and Alfred Jarry have influenced and inspired several animation filmmakers. In order to determine which animation films are surrealist and which not, a determining set of characteristic features has to be established. What is it that makes an animation film surrealist?

Surrealist filmmaker Jan Švankmajer (b. 1934) insists that "Surrealism is everything but art: "world views, philosophy, ideology. psychology, magic'. (Owen 2011: 4) Independently of any assumed influence of surrealism, the technical execution of animation films alone invests them with certain surrealist elements: irrationality, dreaminess, mystery, anti-gravity, fantasy. Collage, a technique highly characteristic to surrealist practice (Max Ernst, Marcel Duchamp, Man Ray, Francis Picabia, etc.), is commonly used in animation film in the form of cut-out (silhouette) animation (Jan Lenica, Walerian Borowczyk, Terry Gilliam, Yuriy Norshteyn, etc.). Art historian Roger Cardinal observes that "the whole idea of the animated film is to suppress the categories of normal perception ... [and to] annihilate the very conditions of rationality" (Wells 2002: 5). Hence every animation film is encoded with a certain surrealist undercurrent, irrationality. Animation film is essentially about creating an illusion (Pikkov 2010: 14). "The cartoon format has continually propagated this restatement of Surrealism as somehow being that of the 'wacky' and the 'weird' merely for its own sake." (Norris 2007: 86) Thus animation film features a number of typically surrealist characteristics, yet it is not regarded as surrealist in general. At which point does animation film become more surreal than "normal" and hence "properly" surrealist? How to measure the degree of surrealism in animation film?

\section{THE CONSISTENCY OF SURREALISM}

Among other things, surrealism has been described as a certain form of realism: sur- realism. According to animation theorist Paul Welles, the illusion of realism induced in animated film is hyper-reality. The term "hyperrealism" was introduced by the French cultural theorist Jean Baudrillard to designate "a hyperreality, a simultaneity of all the functions, without a past, without a future, an operationality on every level" (Baudrillard 1994: 78). Semiotician Umbert Eco employs the notion of hyper-reality to describe Disneyland where absolutely everything is artificial, yet seems more real than reality itself. In Understanding Animation (1998) Wells attempts to map the essence of realism in animation film. In the study of realism, he proposes Disney's films, which he calls hyper-real, as a central point of reference (Pikkov 2010: 99). Thus, following Welles, we should move along an axis that has realist films on one end, nonrealist (abstract) films on the other end and hyper-real Disney's films in the middle. On the diagram below (Figure 1) I have depicted the scale of realism suggested by Wells.

When discussing realism in animation film, it should be borne in mind that animation is a symbiosis of fine art and cinema, which also defines the paradigm of realism in animation film - it is not about copying of reality, but about portraying it as truthfully as possible; an attempt to represent the real world as closely to the original as possible.

Returning to surrealism as a form of realism, we can add a vertical axis to Wells's diagram that defines the degree of surrealism in the paradigm of realism (Figure 2).

Surrealism can thus be realist (as in Magritte's style), hype-realist (Dali's style) or abstract (Miró's style).

As the Magritte-Dalí-Miró axis demonstrates (Figure 3), surrealism can manifest in all forms of realism. Surrealism is not the opposite of realism, it is a degree of dislocation in realism. Following again Wells's train of thought, which draws on Disney's style as an example of the most familiar degree of abstraction in animation film, we should use Dali's style (as the most famous example of surrealism) as a central point of reference in mapping surrealism. 

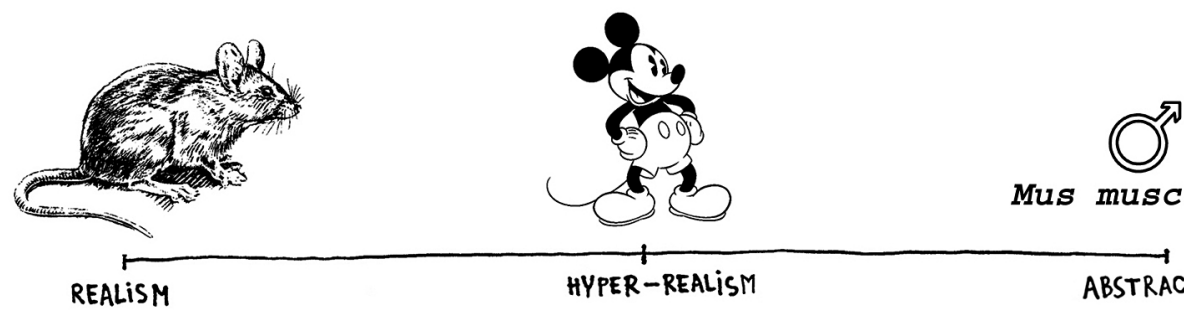

Mus musculus

FIGURE 1

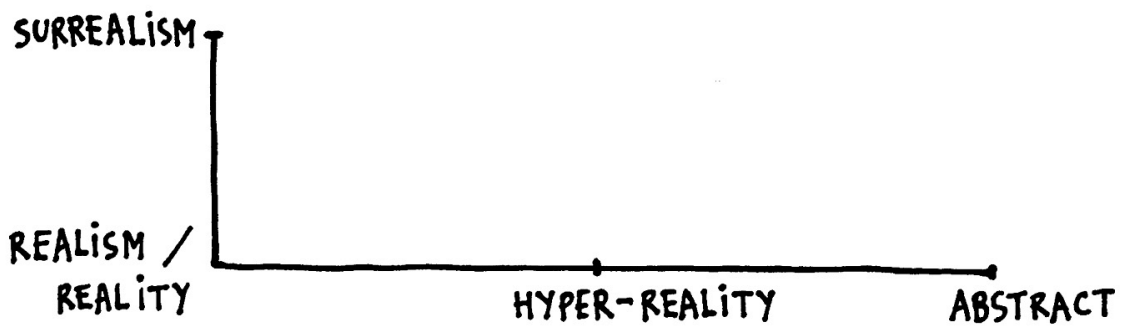

FIGURE 2

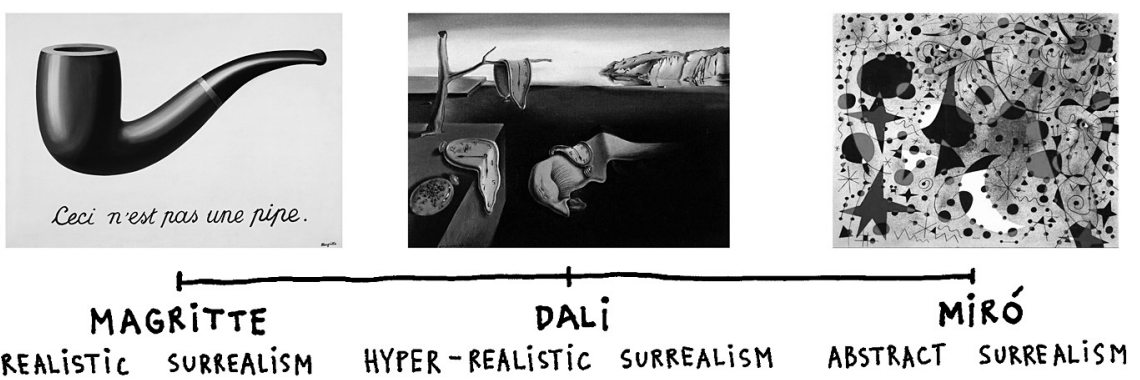

FIGURE 3 
The basic structure of film was formed and developed soon after the birth of cinema (with the exception of sound, which was added later) and has remained basically intact ever since. More precisely, film, by combining a number of independent basic elements (art forms), consists of several different structures: we can talk about the structure of story, of image, of sound, etc. On closer observation, it is a multi-patterned pattern. (Pikkov 2010: 60) Hence film consists of a number of independent "disciplines", each of which can be individually assessed as to their degree of surrealism. In animation film we can consider surrealism's effect on:

1. visuals (visual design of film);

2. sound (aural design of film);

3. movement (rhythms and pace of film);

4. storytelling (rationality and logics of film's plot);

5. relations (connections between film's characters).

In Destino, only visuals are surreal, at least when judged against the context of "average" animation films. The sound, movements, storytelling and relations between characters follow rather traditional and commonplace patterns of animation film. When the various disciplines of Destino are considered in terms of their degree of surrealism, the average result is "moderately surreal" (and this only due to Dalís images in the visuals of the film). Surrealism is only an external style in Destino (Figure 4).

However, in any given animation film the disciplines are usually not of equal importance, and each animation film has a dominant - e.g. music in musical film. Thus, the median value of surrealism in all disciplines of an animation film might not lead to a correct assessment, since the dominant of the film has to be considered as well. At the same time it is quite obvious that an excessively intricate analysis might lose track of the film as a whole. In Surrealism and Cinema, Michael Richardson (2006:3) also emphasizes that precisely the film as a whole should provide the basis for defining surrealism.

Hence, an examination of surrealism in animation film should not proceed from individual disciplines; rather, a film should be considered as a whole in order to detect the degree to which it contains the various forms of surrealism. A study of surrealism in animation film should not be based on the physical properties of surrealism (dislocated realism), it should rather take into account the experience of the audience and the context of the filmmaker. The spectator's perception of the film is of utmost importance, and perhaps the only actual criterion of judgment. In other words, if we set aside the essential surrealism of animation film, a film can be thought of as "properly" surrealist only when it is perceived as a surrealist whole. It should be noted, however, that the perception of surrealism itself has changed over time. For example, what appeared scandalous in the surrealism of the 1920s, has by now become a normal part of the paradigm of contemporary art and has lost its shock value. Returning to Destino, I suggest that for me, as a spectator, the visual images of the film come across as surrealist, yet the film does not succeed in creating a surrealist whole. The surrealism of Destino is limited to the surrealist visuals, and the sound, movement, storytelling and relations lack surrealist qualities. Destino does not manage to create the feeling of uncanny that is essential to surrealism.

\section{THE UNCANNY AS THE MEASURE OF SURREALISM IN ANIMATION FILM}

What, then, is it that makes an animation film surrealist? Art historian Hal Foster (cited in Creed 2007: 116) argues that "no given categories, aesthetic or Surrealist, could comprehend Surrealism conceptually", yet "there is one term that comprehends Surrealism - the uncanny". Sigmund Freud suggests in his 1919 essay Das Unheimliche that heimliche relates to home, house, family and everything familiar, as opposed to heimliche, which is a sense of 


\section{"DESTINO"}

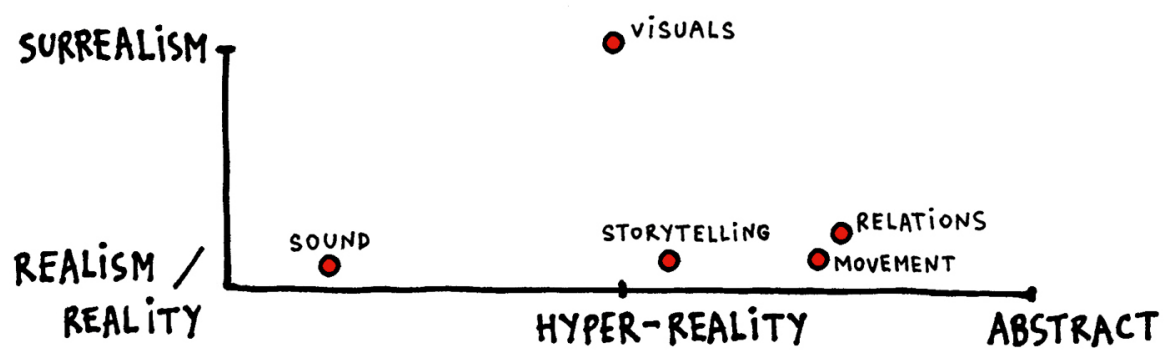

FIGURE 4

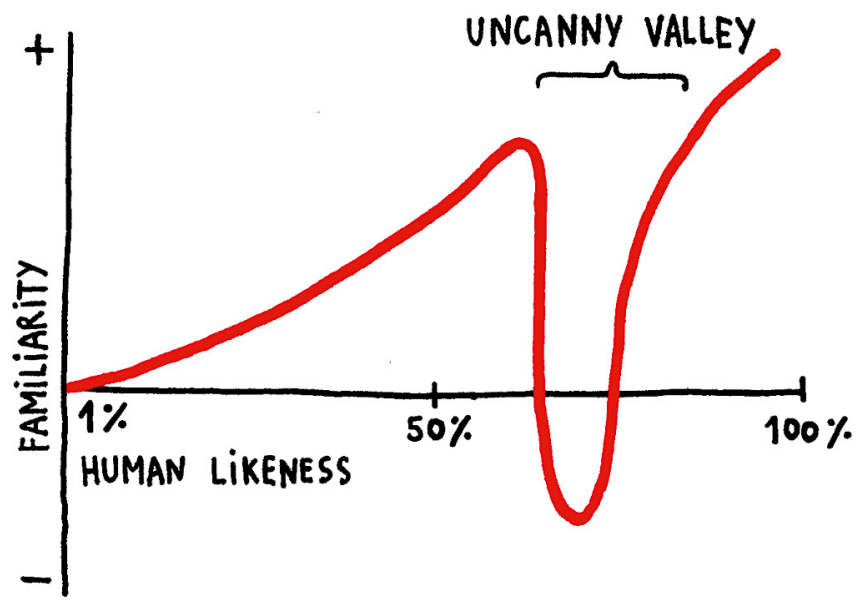

FIGURE 5 
uncanny foreignness, partly reminiscent of what has been experienced before (Freud 1919: 2).

In order to establish the criteria by which to assess the degree of surrealism in animation film, we should concentrate on the notion of "uncanny" and "creating uncanny" or, in other words, on the subconscious uneasiness caused by dislocation of realism. In this context, realism should be considered as something traditional, previously experienced, which, when dislocated (presented in an unfamiliar manner), creates an unconscious sense of uncanny. An unexpected metamorphosis in a film's expected presentation of visuals, sound, movement, storytelling or relations engenders a sense of the uncanny and defines the degree of surrealism in the film.

The notion "uncanny valley" was introduced by Masahiro Mori, a Japanese roboticist (b. 1927). Mori suggested that the more realistic "living" artificial bodies (i.e. of robots, animated characters, etc.) appear, the more emphatic they seem to real human beings (who consider them credible), up to the point where artificial creatures become too human-like and suddenly evoke eeriness instead of empathy. (Pikkov 2010: 80)

Mori's concept of the "uncanny valley" considers only characters and the spectatorial take on them, but as the uncanny is a defining feature of surrealist animation, the film has to be located in the uncanny valley as a whole - the entire experience of the film must be uncanny (Figure 5).

\section{WHO ARE CONSIDERED SURREALISTS BY ANIMATION FILMMAKERS?}

Surrealism is far from being understood in a single and straightforward way, "[s]urrealism is not one thing, and there are as many manifestations of it as there are surrealists." (Richardson 2006: 171) Throughout history the surrealist community has determined on its own who is a surrealist (whose work can be regarded as surrealist) and who is not; during the earliest days it was mostly done by their spiritual leader, Breton. In order to map the terrain of surrealist ani- mation filmmakers, I applied a similar technique, asking animation filmmakers themselves to identify the surrealist community. I began by approaching them with a short questionnaire, asking to name surrealist authors. I then contacted those (surrealist) filmmakers that were mentioned and posed the same questions to them.

First I interviewed Jan Švankmajer "one of the most original and productive of all surrealist film makers" (Richardson 2006: 121), a versatile author who has become one of the leaders of the contemporary surrealist movement. (He is not only a prolific filmmaker but has also served on the editorial board of the Analogan magazine since 1970 and participates in the work of Gambra Gallery in Prague, which is dedicated to exhibiting surrealist art.) In its significance, Švankmajer's contribution to promoting surrealism is similar to Breton's once leading role.

Based on the interviews with ten directors - Jan Švankmajer, Brothers Quay, Priit Pärn, Jerzy Kucia, Igor Kovalyov, Raoul Servais, Piotr Dumala, Koji Yamamura, Atsushi Wada and Mati Kütt - the following diagram (Figure 6) of animation filmmakers was outlined; these are the authors that the community itself defines as surrealists. ${ }^{2}$

The work of these filmmakers reveals a desire not to imitate life, but rather to shed light on the metaphysical world. The personal internal universe and visualisations of the subconscious are of prime interest to them. In their films, numerous readymade objects are animated, rendering the entire cinematic space "alive". According to Švankmajer, "[s] urrealism is a journey into the depths of the soul, like alchemy and psychoanalysis. Unlike both of these, however, it is not an individual journey but a collective adventure." (Hames 2008b: 112)

Collectivity has always been an essential facet of the surrealist project, which does not necessarily manifest as artistic collaboration, but rather as companionship of shared sensibility. The core group of 2013. The recordings are kept in the author's archive. 


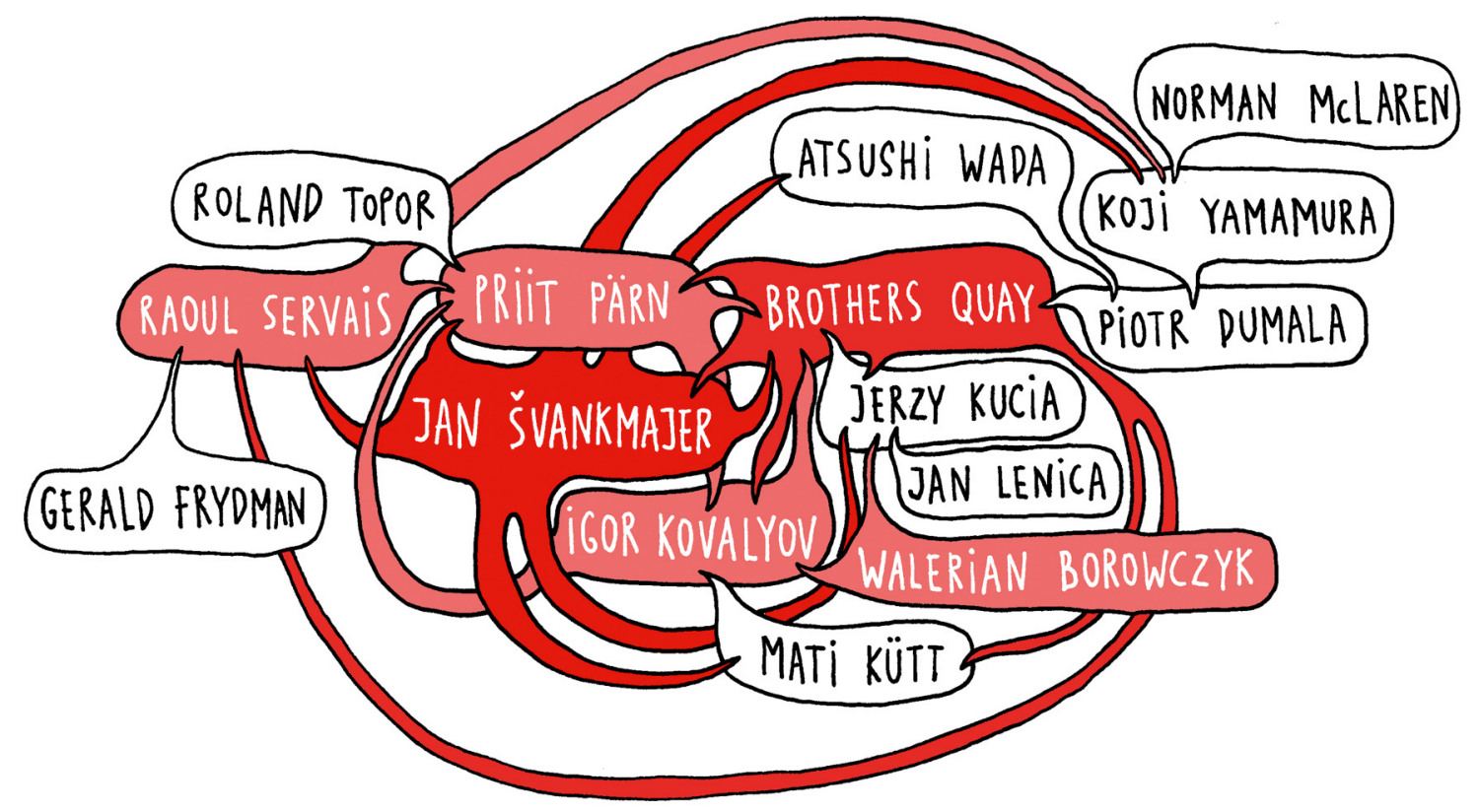

FIGURE 6 
contemporary surrealist animation filmmakers know each other well and meet frequently at film festivals. While not constituting a formal group, they can certainly be regarded as a creative circle of friends. In addition to filmmaking, most of them are also active in fine art, exhibiting prints, paintings and sculptures. The respondents work in more or less equal measure in such animation techniques as puppet animation, hand-drawn animation and mixed media animation. None of them, however, use CGI, which suggests that surrealism in animation film is primarily associated with traditional techniques. "Surrealist movies do not use slow motion, they do not present the images produced by the cinematic apparatus as yet another illusion." (Kuenzli 1996: 10) The works of these surrealist animation filmmakers also rarely rely upon special effects and noticeable digital postproduction, preferring the "natural" style that evokes the sense of uncanny with dislocations in something familiar and traditional.

\section{THE GEOGRAPHY OF SURREALIST ANIMATION}

Authors throughout the world were mentioned in the interviews, yet the filmmakers whose names came up most often belong to the Eastern European cultural terrain (the American-born Brothers Quay have also made films in Poland and in Czech Republic and are the representatives of the "Eastern European cinematic tradition"). The interviews established that the community of animation film directors is rather clear-cut, and a number of authors were mentioned repeatedly (Švankmajer on seven, Brothers Quay on six, Pärn, Kovalyov, Borowczyk and Servais on two occasions). The fact that the point of gravity of surrealist animation appears to be in Eastern Europe can be explained as a continuation of a preexisting tradition, as a strong surrealist group was active in Czechoslovakia during the interwar period, on whose invitation, for example, André Breton visited Prague in 1935 (Bydžovská 2005: 6). "After Paris and Brussels, Prague was one of the most important centres where surrealism was developed by several generations of artists" (ibid., 1). "[P]aradoxically, surrealism greatly expanded in the Czech lands during the war, when it was banned. In the stifling atmosphere of the Protectorate, it represented, for the young generation, an alluring challenge to engage in free creative thought." (ibid., 9). Even after World War II, under the conditions of enforced socialist ideology, surrealism retained its sound footing in Eastern Europe. Jonathan L. Owen observes that "[s] urrealism, in its authentic form, has forever been in revolt against existing ideological and social systems" (Owen 2011: 218). There is a direct correlation between the popularity of surrealism and the degree of personal and creative freedom in the postwar Europe. Michael Löwy, one of the most prominent contemporary theorists of surrealism, argues that "[s]urrealism is not only a stream of Modernism or a chapter in the history of the $20^{\text {th }}$ century avantgarde, but it is also a kind of 'anthropology of human freedom'” (Majmurek 2010: 165). The Surrealist movement has always demonstrated political ambition and in the post-war Eastern Europe it also functioned as an act of protest and resistance. "The Platform of Prague", the Czechoslovakian surrealist manifesto, stated that "[s]urrealism must oppose itself to both Stalinist Communism and Western capitalism" (Owen 2011: 191). In socialist Eastern Europe surrealist thought was in the constant process of development and conceptualization, as demonstrated by the animation films produced in the region. "If no branch of any national cinema has ever succeeded in establishing an uncontaminated Surrealist tradition, Surrealism has nonetheless remained an enduring tendency of both Czech and Polish animation" (Owen 2010: 45). In Priit Pärn's words, "in Soviet animation film, adopting a surrealist point of view was a form of protest, since the authorities preferred funny films with unambiguous messages." ${ }^{3}$ By the second half of the 1980s, the political pressures Recording in the author's archive. 
had started to ease considerably in Estonia and, liberated from the clutches of censorship, the artists were able to enjoy more creative freedom. In 1986, on Pärn's initiative, animation filmmakers Heiki Ernits (b. 1953), Rao Heidmets (b. 1956), Miljard Kilk (b. 1957), Mati Kütt (b. 1947), Hillar Mets (b. 1954), Priit Pärn (b. 1946), Tõnu Talivee (b. 1951), Riho Unt (b. 1956) and Hardi Volmer (b. 1957) formed the Tallinnfilm Surrealists group (see also Laaniste 2009: 141), with Kalju Kivi (b. 1951) and Vahur Kersna (b. 1962) joining them at a later date. As the group included the majority of Estonian animation filmmakers of the late 1980s, the Estonian animation film of the time was decisively surrealist in nature. Although the Tallinnfilm Surrealists lacked a written platform (manifesto, programme), they had, for example, a logo that was printed on shirts and other items for promoting the group. The Tallinnfilm Surrealists showed their art works primarily at group exhibitions, but its members also continued to make animation films, thus establishing a strong surrealist frame of reference in Estonian animation. ${ }^{4}$

A good example of how surrealistinspired art gave direct impulses to animation film is Mati Kütt's piece Smoked Sprats (Sprotid), featuring a tin jar filled with female torsos (displayed at a group exhibition in Vaasa, Finland, 1989), and his animation film Smoked Sprat Baking in the Sun (Sprott võtmas päikest, Tallinnfilm, 1992). Both works are centred around the image of an imprisoned, female, golden fish. The 23-minute film is essentially an opera, or more precisely an underwater animation opera. By intertwining the opposite worlds and urges (above the water/ under the water, two-dimensional/threedimensional, fear of castration/reproduction drive, etc.), Kütt tells the story of a golden fish who, in the name of its freedom and happiness, is ready to fulfill any three wishes. Yet freedom attained in this manner is more than questionable to both the wisher and the freedom-seeker. Smoked

4 Author's video interviews with Tallinnfilm Surrealists in the spring of 2013 in Tallinn. Recordings in the archive of the author.
Sprat Baking in the Sun can also be interpreted as a series of monologues of the subconscious, stemming from the collision of desires and norms. The film's soundtrack is composed of dramatic opera tunes with naïve libretto in German, investing the story with a sense of grotesque and pathos. The uncanny - the primary condition of surrealism - is easily perceived in Smoked Sprat Baking in the Sun. The film's visuals present a fish with legs living on the dry land and a man inhabiting the underwater domain; the film's sound features traditional opera, presented in an overdramatized manner; the movement and gravity are transformed into metaphysical underwater weightlessness; the story is the well-known fairy-tale of Golden Fish by Alexander Pushkin, yet the elements of the tale are over-amplified; the characters of the film appear to be a fish and a fisherman, but their relationship is interlaced with an unexpected lustful sexual innuendo. Each discipline of the film presents familiar elements in a dislocated atmosphere - Smoked Sprat Baking in the Sun employs surrealist forms and imagery. Hence, according to the system of assessment introduced above, the film is on average "very surrealist" (Figure 7).

Other Estonian surrealist animation films of the period include Enchanted Island (Nõiutud saar, Unt, Volmer, 1985), Papa Carlo's Theatre (Papa Carlo teater, Heidmets, 1988), Noblesse oblige (Pärna, Heidmets, 1989), Labyrinth (Labürint, Kütt, 1989), Hotel E (Hotell E, Pärn 1992), etc. "Sixty years after the birth of surrealism in France the Estonian animation filmmakers declared themselves surrealists! Slightly weird, but art reflects its times and surrealist ideas made a perfectly befitting mirror to the crumbling Soviet Union." (Pikkov 2011: 94)

Surrealism, born in Paris of the 1920s, found a new hotbed in post-World War II Eastern Europe, where it became a contraculture in opposition with the dominant cultural politics, inspiring many artistic minds. Surrealism constituted one of the keystones of the Soviet underground avant-garde art (Laaniste 2009: 134). The surrealist animation 
film of the post-war period was a confrontational art form, seeking to challenge the boundaries of its field with absurdity and irony. The common denominator of cultural politics in the former Soviet sphere was socialist realism, basically a form of realism. Similarly to surrealism it first manifested in literature and subsequently gave impulses to other art forms. Drawing primarily on Hegel's thought, the Hungarian Marxist György Lukács developed his theory of art, or more precisely of literature, that served the needs of Stalinist Russia particularly well, as literature had traditionally been a leading art form in Russian culture (Kangilaski 2013: 20). In the early 1930s socialist realism became the dominant art paradigm in the Soviet Union and in 1934 Andrei Zhdanov, the chairman of the Supreme Soviet of the Communist Party, declared at the Soviet Writer's Congress that socialist realism is characterized by truthful and historically concrete depictions of reality in its revolutionary development, by party-mindedness (which meant illustration and justification of the party politics), and by popular appeal (ibid.). At the same event, Karel Teige, one of the leaders of the Czechoslovakian avant-garde, proposed to combine the notions of surrealism and socialist realism (Hames 2008a: 22). Indeed, the ideology and propaganda of the socialist society, which combined realism with fantastic images of bright future, shared in part the surrealist impulse to change the reality, but it relied on idealization, not dislocation of reality.

Cultural forms have frequently developed in the process of contradictory interaction, which also explains the popularity of surrealism in post-war Eastern Europe limited personal freedom and the officially endorsed socialist realism called for the counterweight of surrealism (Figure 8). In Western Europe, where such (cultural) politics did not exist, surrealism was soon marginalized, and its former avant-garde thrust was safely transformed into neutered symbols of popular culture and consumer items.

\section{CONCLUSION}

The study of surrealism in animation film facilitates a broader understanding of impulses and interactions between filmmakers, it widens interpretational horizons of particular filmic texts and enhances awareness of authorial positions. Surrealism has always been intimately related to authorial worldviews and attitudes, which are typically socially sensitive and critical. Surrealism can also be regarded as an indicator of personal freedom, and an examination of its spread and forms of expression sheds light on patterns of social development.

Identifying animation filmmakers and their films as surrealist has little value on its own, yet such classification helps to better understand the conditions of the time and the political system under which these filmmakers lived and produced their works. Instead of assessing the individual disciplines of animation film, the films should be analysed as integral wholes, in order to determine to what extent they contain surrealist modes of expression. Surrealism in animation film should be judged on the basis of spectatorial experience and authorial contexts.

As established by interviews conducted for this study, the central group of contemporary surrealist animation filmmakers includes Jan Švankmajer, Brothers Quay, Priit Pärn, Igor Kovalyov, Walerian Borowczyk and Raoul Servais. While these authors do not constitute a formally established group, they can still be regarded as a creative circle of friends. We saw that most of surrealist animation filmmakers come from or have been active in Eastern Europe. The popularity and wide spread of surrealism in post-World War II Eastern Europe can be explained as a continuation of a tradition (Prague was already a strong centre of surrealism during the interwar period), yet it is partly also an act of protest against socialist realism of the Soviet period. 
"SPROTT VŌTMAS PÄIKEST"

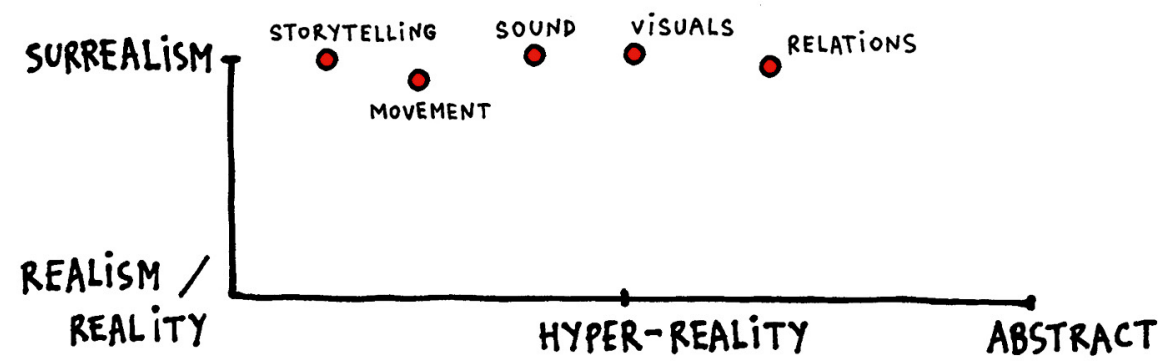

FIGURE 7

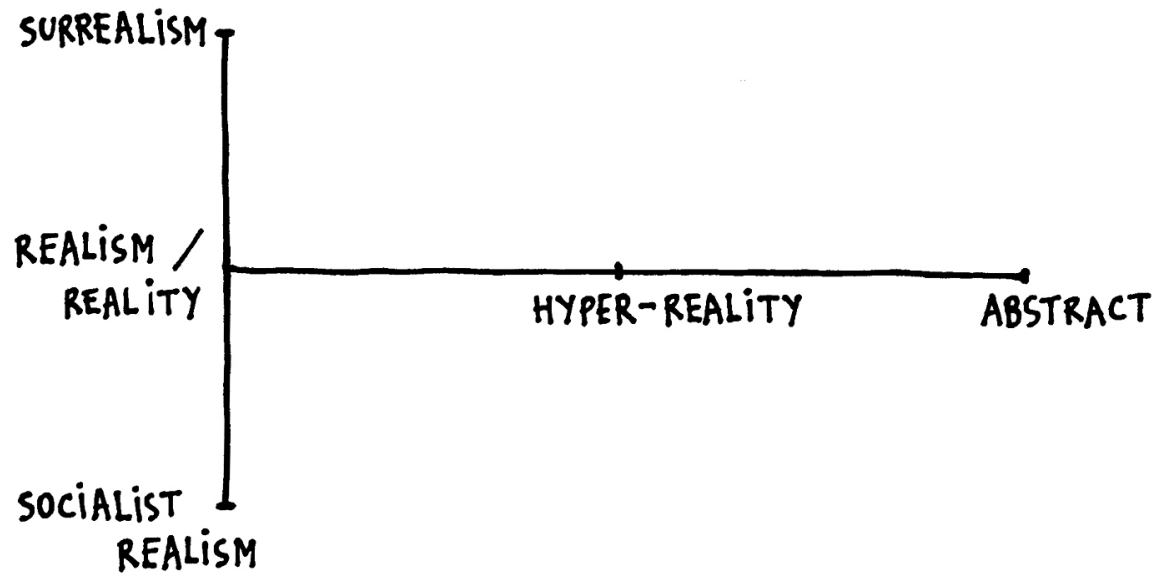

FIGURE 8 


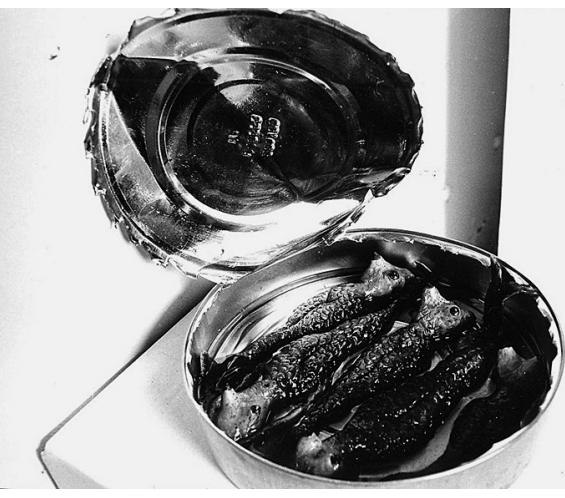

1

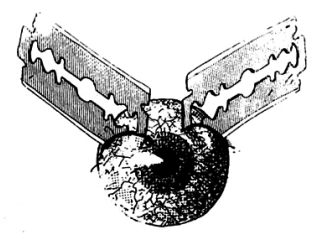

《TALLIN N F I MI ) sürrealstid

3

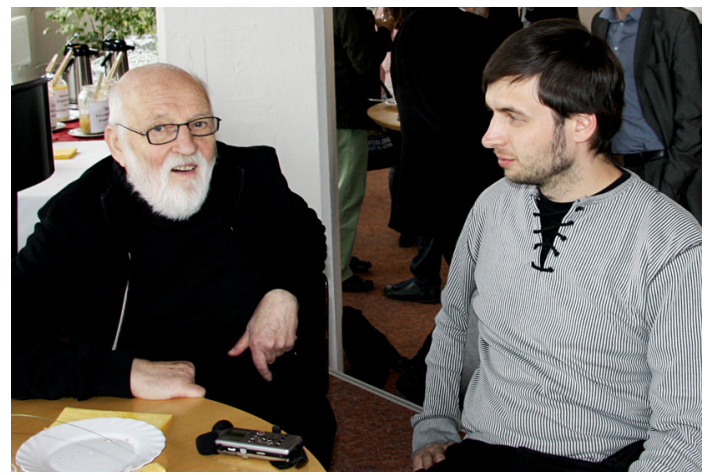

Mati Kütt, Smoked Sprats, 1989.

Photo by Tônu Talivee.

Mati Kütt, Smoked Sprat Baking in the Sun.

Tallinnfilm, 1992.

Logo of the Tallinnfilm Surrealists.

The Tallinnfilm Surrealists: (in the front, from the left) Tônu Talivee, Miljard Kilk and Hardi Volmer, behind him Riho Unt; (standing, from the left): Rao Heidmets, Mati Kütt, Priit Pärn and Heiki Ernits. Photo by Tônu Talivee.

Jan Švankmajer giving an interview to the author of the article at 2011 Dresden Film Festival. 


\section{REFERENCES}

Baudrillard, J. 1994. Simulacra and Simulation. Trans. S. F. Glaser. Ann Arbor: University of Michigan Press. Brandon, R. 1999. Surreal Lives: The Surrealists 19171945. New York: Grove Press.

Breton, A. [1924] 2010. First Manifesto of Surrealism 1924. Trans. A. S. Kline. http://uploads.worldlibrary.net/ uploads/pdf/20121102214233manifestopdf_pdf.pdf (7 August 2013).

Bydžovská, L. 2005. 'Against the current:The story of the surrealist group of Czechoslovakia' - Papers of Surrealism, 3, http://www.surrealismcentre.ac.uk/ papersofsurrealism/journal3/acrobat_files/lenka.pdf (7 August 2013).

Creed, B. 2007. 'The untamed eye and the dark side of surrealism: Hitchcock, Lynch and Cronenberg'. G. Harper, R. Stone (eds.), The Unsilvered Screen: Surrealism on Film. London: Wallflower Press, 115-133. Freud, S. 1919. 'The uncanny'. http://web.mit.edu/ allanmc/www/freud1.pdf (7 August 2013).

Hames, P. 2008a. 'The film experiment'. - P. Hames (ed.), Dark Alchemy: The Cinema of Jan Švankmajer. London, New York: Wallflower Press, 8-39.

Hames, P. 2008b. 'Interview with Jan Švankmajer'. P. Hames (ed.), Dark Alchemy: The Cinema of Jan Švankmajer. London, New York: Wallflower Press, 104139.

Kangilaski, J. 2013. 'Kunstnike lootused'. - J. Kangilaski (ed.), Eesti kunsti ajalugu. 1940-1991. I osa. Tallinn: Eesti Kunstiakadeemia, Sihtasutus Kultuurileht, 16-22. King, E. H. 2007. Dali, Surrealism and Cinema. Harpenden: Kamera Books.

Kuenzli, R. E. 1996. 'Introduction'. - R. E. Kuenzli (ed.), Dada and Surrealist Film. Cambridge, London: The MIT Press, 1-12.

Laaniste, M. 2009. 'Karikatuur ja/või kunst.

Valdkondade vahekorrast Eestis Priit Pärna loomingu näitel / Cartoons and/or art: On the relationship of two fields in Estonia, based on Priit Pärn's creative career'. Kunstiteaduslikke Uurimusi, 18, 1-2, 111-150.

Majmurek, J. 2010. ‘Utopia, dystopia, escape: Surrealism and Polish science fiction / fantasy cinema'. - K. Wielebska, K. Mikurda (eds.), A Story of Sin: Surrealism in Polish Cinema. Krakow, Warsaw: Korporacja Ha!art, 160-185.

Moine, R.; Taminiaux, P. 2006. 'From surrealist cinema to surrealism in cinema: Does a surrealist genre exist in film?' - Yale French Studies, 109, 98-114.

Norris, V. 2007. “Interior logic': The appropriation and incorporation of popular surrealism into classical American animation'. - G. Harper, R. Stone (eds.), The Unsilvered Screen: Surrealism on Film. London: Wallflower Press, 72-89.

Owen, J. L. 2010. 'Motion without escape: The bleak surrealism of Czech and Polish animation: -

K. Wielebska, K. Mikurda (eds.), A Story of Sin: Surrealism in Polish Cinema. Krakow, Warsaw: Korporacja Ha!art, 44-59.

Owen, J. L. 2011. Avant-Garde to New Wave:

Czechoslovak Cinema, Surrealism and the Sixties. New York, Oxford: Berghahn Books.

Pikkov, Ü. 2010. Animasophy: Theoretical Writings on the Animated Film. Trans. E. Näripea. Tallinn: Estonian Academy of Arts.

Pikkov, Ü. 2011. 'Sürrealismi tee eesti animatsioonifilmi:' - Teater. Muusika. Kino, 3, 94.

Richardson, M. 2006. Surrealism and Cinema. Oxford: Berg.

Wells, P. 2002. Animation and America. New Brunswick: Rutgers University Press.

Williams, L. 1981. Figures of Desire: A Theory and Analysis of Surrealist Film. Berkeley, Los Angeles, Oxford: University of California Press. 